\title{
How GreenSQA Tests Biometric Authentication for Electoral Processes
}

\author{
Eider Mauricio Aristizábal Erazo ${ }^{1}$ \\ ${ }^{1}$ GreenSQA S.A., Colombia, earisti@greensqa.com. eidermauricio@hotmail.com
}

\begin{abstract}
Governmental Biometric Application" for "Colombian Congress Elections", GreenSQA S.A. developed a very fast software test automation framework and a "blue print" for testing biometric authentication and citizen registration applications, integrated with Visual Studio 2013 and supported on Microsoft ALM (Application Lifecycle Management) to manage, develop and execute more than 26.000 automated functional test cases and analyzed 1027 teras of database rows in just 9 days. Colombian Democratic Politics require to comply with maximum quality standards to reduce risks of fraud, like any kind of ID impersonation or a dead person ID usage.
\end{abstract}

Keywords - Application Life Cycle Management, Scrum, Non Functional Tests, Automated Tests, Biometric Applications.

Digital Object Identifier (DOI): http://dx.doi.org/10.18687/LACCEI2015.1.1.261

ISBN: 13 978-0-9822896-8-6

ISSN: 2414-6668

$1^{\text {th }}$ LACCEI Annual International Conference: “Engineering Education Facing the Grand Challenges, What Are We Doing?” July 29-31, 2015, Santo Domingo, Dominican Republic ISBN: 13 978-0-9822896-8-6

ISSN: $2414-6668$

DOI: http://dx.doi.org/10.18687/LACCEI2015.1.1.261 


\title{
How GreenSQA Tests Biometric Authentication for electoral processes
}

\author{
Eider Mauricio Aristizábal Erazo, Chief Technology and Innovation Officer \\ GreenSQA S.A., Colombia, earisti@greensqa.com.eidermauricio@hotmail.com
}

\begin{abstract}
Resumen- Con el objetivo de certificar la "Aplicación Gubernamental de Biometría” para las "Elecciones Colombianas del Congreso", GreenSQA desarrolló un liviano Framework de automatización y un proceso para probar las aplicaciones de Autenticación biométrica y Registro de ciudadanos. Integradose con Visual Studio 2013 y apoyándose en Microsoft ALM (Application Lifecycle Management) logra gestionar, desarrollar y ejecutar más de 26.000 casos de pruebas automáticos y analizar teras de filas de información de $\mathrm{DB}$ en tan solo 9 días. Las Políticas Democráticas de Colombia requieren cumplir con los máximos estándares de Calidad para reducir riesgos de fraude, por ejemplo suplantación de cédula o uso de cédulas de personas fallecidas.
\end{abstract}

Abstract- in order to certify "Governmental Biometric Application" for "Colombian Congress Elections", GreenSQA S.A. developed a very fast software test automation framework and a "blue print" for testing biometric authentication and citizen registration applications, integrated with Visual Studio 2013 and supported on Microsoft ALM (Application Lifecycle Management) to manage, develop and execute more than 26.000 automated functional test cases and analyzed 1027 teras of database rows in just 9 days. Colombian Democratic Politics require to comply with maximum quality standards to reduce risks of fraud, like any kind of ID impersonation or a dead person ID usage.

Keywords- Application Life Cycle Management, Scrum, Non Functional Tests, Automated Tests, Biometric Applications.

\section{INTRODUCTION}

One of our best customers contacted us for an important and national context project, we were committed to certify quality of the "Biometric authentication" application, for which we decided to use an ALM - Application Lifecycle Management quality testing and quality management solution. Biometric authentication software is necessary to ensure that the any present person in the voting elections is who declared to be. That application was developed to be use during "Colombian Congress and Presidential elections" that took place on March 9 and May 25 of 2014.

The testing process was supported by: Team Foundation Server "Agile Scrum process template" and Visual Studio 2013. It was also necessary to expand GreenSQA AiMaps ${ }^{\circledR}$ and GreenSQA INFramework ${ }^{\circledR}$ testing technologies to achieve testing goals with a minimum of Target System Machines invasion (Install as minimum software as possible on target machine), also adjustments to the System Under Test to ensure maximum quality level (none errors in all executed test cases) were needed. With that level of demand in terms of quality of the solution, it was necessary to implement a strong and granular testing process that ensure the desired result and avoid any kind of legal sanction for our client as mandatory Article 39 of 2011 Colombian Law dictates: "National Civil Registry, will implement, for the next elections, biometric identification of voters". With an accurate and reliable testing of biometric authentication process, GreenSQA contribute to bring transparency and security to the Colombian national electoral process.

That experience allowed us to develop and maintain test components for Biometric Authentication Application and Citizen Registration Application that can be easily modified and focused over any electoral event and not only on Colombian territory but also in other countries and scenarios. To date we apply our experience and reusable components to:

1) Testing Citizen Registration Application prior to electoral Events: Any citizen can be subscribed to any desired voting stand on any national valid place, which is several weeks' previous to electoral events.

2) Testing Biometric Authentication during Electoral Events: 2015 National Mayor Elections or any electoral event.

3) Testing Data Migration: Test the correctness of imported database information rows from official government foundation information, that implies to cross millions of table rows as the result of analyze quickly millions of millions of crossed row of information.

\section{ABOUT GREENSQA COMPANY}

GreenSQA SA is one of the leading and most recognized companies specialized in software testing services in Colombia. Last year we were recognized by Microsoft in the WPC event with first place at LATAM in ALM Competency and we also were ALM Worldwide Award Finalist. Since 2002, when we started operations, we have been responsible for ParqueSoft's Quality Strategy, condition thanks to which our testing methodology has been exposed to multiple work conditions (such as technology platforms, software development languages, databases, programming paradigms,

$1^{\text {th }}$ LACCEI Annual International Conference: “Engineering Education Facing the Grand Challenges, What Are We Doing?” 
infrastructure and communications, multiple economy sectors, product sizes and complexity, among others).

To date, we have performed over 15,000 successful software testing projects with hundreds of small, medium and large enterprises across all market sectors and across the public and private sector such as: Telecommunications, Gas \& Oil, Financial, Healthcare, Solidarity, Government, Educational and Commercial, Business Process Management.

We have the ISO 9001 certification of our system and process since 2006 and we are currently in the final stages of the implementation process of CMMISVC 1.3 International model, which ends early in June this year with the SCAMPI (A) appraisal ML 3 authenticating the good practices of our system software testing services. Our mission is to provide quality to our client's business by providing testing services tailored to their needs, supplemented with our knowledge, experience, tools for test automation and technology developed by our teams to make it easier, faster and more efficient.

\section{CUSTOMER SITUATION}

The process performed by our customer without GreenSQA tests is the following:

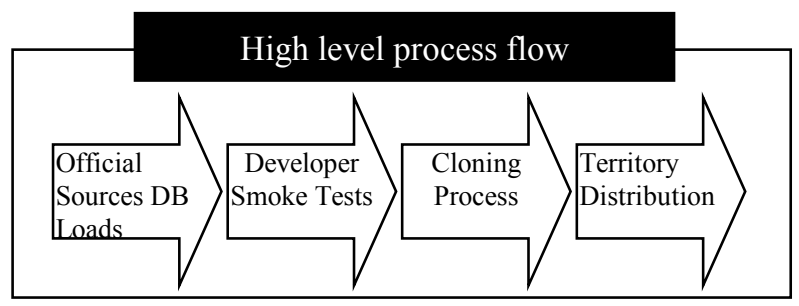

Fig. 1 Global Customer Process.

1) Official Sources DB Loads: Consists in take official government information and load it into different master machines.

2) Developer Smoke Tests: Developers do their tests but without external tester perspective.

3) Cloning Process: After Testers and User Acceptance Tests (again without external tester perspective) master machines were cloned (in blocks of 300 physical machines at the same time).

4) Territory Distribution: Once machines were cloned they were distributed over 174 Colombian places.

The challenge of ensure that the application works correctly, was assigned to GreenSQA S.A. who must certify the quality of master computers containing the "Biometric Application" to proceed with logistical process for copying and distribution in the Colombian territory, which was to send
8500 clones to 174 cities. All "Clone" computers lacked of any validity without the GreenSQA S.A. certification seal.

Certification, cloning and distribution of 8500 computers were performed in 9 calendar days remaining until the electoral event (That dead line, could not be postponed). Due security and confidentiality reasons, GreenSQA had to develop and refine the test robot in only two days, just before starting the logistics process for cloning and distribution in the Colombian territory. The machines had a reduced hardware and could not install additional software on them; also the execution environment of the test should be defined directly on the master machine, and in a comprehensive manner, i.e. for 174 cities in all polling stations. Because the number of tests to be executed for all of the 174 cities is so high and corresponds to system test cases, it was impossible to run them manually.

Our customer was aware that the project is critical and that the time box is very short, so our commercial offering was based on: agility, quality, low cost, reliability and continuous value generation, those features can only be achieved with "Scrum Process Template" and a specialized and committed ALM (Application Life Cycle Management) team like GreenSQA members.

\section{A. Specific Solution}

The most efficient way to deliver for the customer that amount of work was using migration tests, load tests and coded UI tests (automated) and taking into account that must be executed in a time window of seven days because we already had wasted two days in the development of tests robots. Using the following tools: VS2013, C \# language, plus "GreenSQA INFramework" helper libraries and "GreenSQA AiMaps" automation tool that can be easily integrated with Visual Studio Coded UI Tests Tool, We created an agile scrum project in Visual Studio Online, and extraordinarily we have developed, administered and implemented as the best style of "Fast and Furious" the record amount of 26.515 automated test cases, and 1027 teras of rows were analyzed. During all those tests executions, the robot detected 3 main critical errors, which after being corrected promptly, prevented our customer of being involved in legal issues as political demands or electoral frauds. The robot is portable, and was packaged in a USB storage from which tests were executed for each master machine (the machine that would be cloned and distributed to several voting stations), with that USB Mechanism we will not impact the final execution environment of the machines to be certified.

For future similar works we defined a technical blue print and reusable architectural definitions to speed-up and provide high quality to Biometric Authentication and Citizen Registration Applications core business processes. 


\section{GENERIC TEST SOLUTION STRATEGY}

We add fast and reliable tests after the first two stages of the global process in two scopes Citizen Registration Application and Biometric Authentication Application:

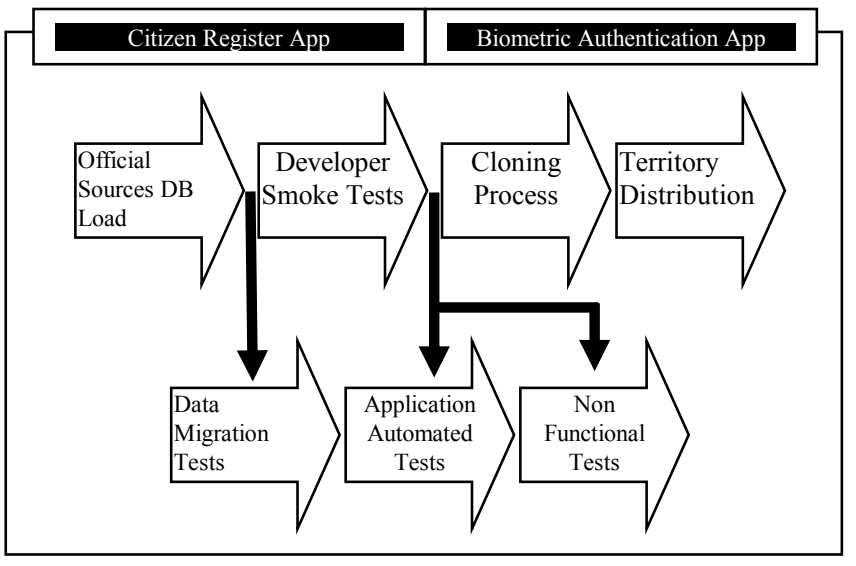

Fig. 2 Global Customer Process with GreenSQA Tests.

1) Data Migration Tests: Consists in assert that official government information is correctly loaded it into different master machines.

2) Application Automated Tests: Consists in perform functional tests via robot in a very fast and efficient speed over Biometric Authentication Application and Citizen Registration Application.

3) Non Functional Tests: Consists in emulate real user loads during a real peak hour scenario.

\section{A. Scope: Citizen Register Application}

Recommended tests of a Citizen Registration Application to be used previous (several weeks before) electoral events:

TABLE I

SCOPE: CITIZEN REGISTER APP

\begin{tabular}{|c|l|c|c|}
\hline \multirow{2}{*}{$\begin{array}{c}\text { Test } \\
\text { case } \\
\text { Num. }\end{array}$} & \multicolumn{3}{|c|}{ Tests Configuration } \\
\cline { 2 - 4 } 1 & \multicolumn{1}{|c|}{ Test Case Scenario } & Test flow & Type of test \\
\hline \multirow{2}{*}{2} & $\begin{array}{l}\text { Check if stand machine } \\
\text { contains all possible voters }\end{array}$ & Positive & $\begin{array}{c}\text { Data Migration } \\
\text { Tests }\end{array}$ \\
\cline { 2 - 4 } 3 & $\begin{array}{l}\text { Check if citizen basic data is } \\
\text { correct }\end{array}$ & Positive & $\begin{array}{c}\text { Data Migration } \\
\text { Tests }\end{array}$ \\
\cline { 2 - 4 } 3 & $\begin{array}{l}\text { Configure application stand to } \\
\text { perform register tests }\end{array}$ & Positive & $\begin{array}{c}\text { Application } \\
\text { Automated Tests }\end{array}$ \\
\cline { 2 - 4 } 4 & $\begin{array}{l}\text { Register a valid person on } \\
\text { current stand }\end{array}$ & Positive & $\begin{array}{c}\text { Application } \\
\text { Automated Tests }\end{array}$ \\
\cline { 2 - 4 } 5 & $\begin{array}{l}\text { Register a non-valid person on } \\
\text { current stand }\end{array}$ & Negative & $\begin{array}{c}\text { Application } \\
\text { Automated Tests }\end{array}$ \\
\cline { 2 - 4 } 6 & Check tablet battery duration & Positive & $\begin{array}{c}\text { Non Functional } \\
\text { Tests }\end{array}$ \\
\cline { 2 - 4 } 7 & $\begin{array}{l}\text { Check application performance } \\
\text { during all tests }\end{array}$ & Positive & $\begin{array}{c}\text { Non Functional } \\
\text { Tests }\end{array}$ \\
\cline { 2 - 4 }
\end{tabular}

\begin{tabular}{|c|l|l|c|}
\cline { 2 - 4 } 8 & $\begin{array}{l}\text { Simulate user registration load } \\
\text { on national central server }\end{array}$ & Positive & $\begin{array}{c}\text { Non Functional } \\
\text { Tests }\end{array}$ \\
\cline { 2 - 4 } & $\begin{array}{l}\text { Find maximum concurrency on } \\
\text { national central server }\end{array}$ & Positive & $\begin{array}{c}\text { Non Functional } \\
\text { Tests }\end{array}$ \\
\cline { 2 - 4 } 10 & $\begin{array}{l}\text { Find rupture point on national } \\
\text { central server using stress tests }\end{array}$ & Positive & $\begin{array}{c}\text { Non Functional } \\
\text { Tests }\end{array}$ \\
\hline
\end{tabular}

\section{B. Scope: Biometric Authentication Application}

Recommended tests of a Biometric Authentication Application to be used during electoral events:

TABLE II

SCOPE: BIOMETRIC AUTHENTICATION APP

\begin{tabular}{|c|c|c|c|}
\hline \multirow{2}{*}{$\begin{array}{l}\text { Test } \\
\text { case } \\
\text { Num. }\end{array}$} & \multicolumn{3}{|c|}{ Tests Configuration } \\
\hline & Test Case Scenario & Test flow & Type of test \\
\hline 1 & $\begin{array}{l}\text { Check if all persons IDs were } \\
\text { migrated and find ones who } \\
\text { were not migrated }\end{array}$ & Positive & $\begin{array}{c}\text { Data Migration } \\
\text { Tests }\end{array}$ \\
\hline 2 & $\begin{array}{l}\text { Check if the correct person } \\
\text { registered stand is migrated }\end{array}$ & Positive & $\begin{array}{c}\text { Data Migration } \\
\text { Tests } \\
\end{array}$ \\
\hline 3 & $\begin{array}{l}\text { Check if citizen witness were } \\
\text { migrated }\end{array}$ & Positive & $\begin{array}{c}\text { Data Migration } \\
\text { Tests } \\
\end{array}$ \\
\hline 4 & $\begin{array}{l}\text { Check if government } \\
\text { supervisors were migrated }\end{array}$ & Positive & $\begin{array}{c}\text { Data Migration } \\
\text { Tests } \\
\end{array}$ \\
\hline 5 & $\begin{array}{l}\text { Configure application stand to } \\
\text { perform authentication tests }\end{array}$ & Positive & $\begin{array}{c}\text { Application } \\
\text { Automated Tests }\end{array}$ \\
\hline 6 & $\begin{array}{l}\text { Register a valid person on } \\
\text { current stand }\end{array}$ & Positive & $\begin{array}{c}\text { Application } \\
\text { Automated Tests }\end{array}$ \\
\hline 7 & $\begin{array}{l}\text { Register non Valid Person on } \\
\text { current stand }\end{array}$ & Negative & $\begin{array}{c}\text { Application } \\
\text { Automated Tests }\end{array}$ \\
\hline 8 & $\begin{array}{l}\text { Check Finger print reader } \\
\text { availability }\end{array}$ & Positive & $\begin{array}{c}\text { Application } \\
\text { Automated Tests } \\
\text { Human Assisted }\end{array}$ \\
\hline 9 & $\begin{array}{l}\text { Check first ticket printer with } \\
\text { paper availability }\end{array}$ & Positive & $\begin{array}{c}\text { Application } \\
\text { Automated Tests }\end{array}$ \\
\hline 10 & $\begin{array}{l}\text { Check second ticket printer } \\
\text { with paper availability }\end{array}$ & Positive & $\begin{array}{c}\text { Application } \\
\text { Automated Tests }\end{array}$ \\
\hline 11 & $\begin{array}{l}\text { Check third ticket non printer } \\
\text { with paper availability }\end{array}$ & Negative & $\begin{array}{c}\text { Biometric } \\
\text { Automated Tests }\end{array}$ \\
\hline 12 & $\begin{array}{l}\text { Register valid person of other } \\
\text { stand }\end{array}$ & Positive & $\begin{array}{c}\text { Application } \\
\text { Automated Tests }\end{array}$ \\
\hline 13 & Register non existing person & Negative & $\begin{array}{c}\text { Application } \\
\text { Automated Tests }\end{array}$ \\
\hline 14 & $\begin{array}{l}\text { Simulate user authentication } \\
\text { load of one peak hour }\end{array}$ & Positive & $\begin{array}{c}\text { Non Functional } \\
\text { Tests }\end{array}$ \\
\hline 15 & Find maximum concurrency & Positive & $\begin{array}{c}\text { Non Functional } \\
\text { Tests }\end{array}$ \\
\hline 16 & $\begin{array}{l}\text { Find rupture point on national } \\
\text { central server using stress tests }\end{array}$ & Positive & $\begin{array}{c}\text { Non Functional } \\
\text { Tests }\end{array}$ \\
\hline 17 & $\begin{array}{l}\text { Check final day data backup } \\
\text { and export }\end{array}$ & Positive & Functional Tests \\
\hline
\end{tabular}

\section{Generic Test Automation Environment}

As shown in figure 3 (see next page), is necessary to define a components diagram to statically structure tests logic source code. Core business components are described as follows: 
1) Biometric Authentication Application: Biometric Application under test, we model Graphical user Interface and Database as standard UML provided interfaces.

2) Citizen Registration Application: Registration Application under test, we model Graphical user Interface and Database as standard UML provided interfaces.

3) Tests Application Launcher: Principal container of tests automation logic, this component presents a Graphical User Interface to the tester who will operate tests, and orchestrates Microsoft and GrenSQA tests components providing test data extracted directly from a valid database. Test Logic Layer Components, will execute listed Automated Test cases as shown in tables I and II; at the same time log reports will be assigned to development team via TFS Bug Work Item.

4) GreenSQA INframework $®$ : Set of libraries to speedup test automation process, this contains classes like Keyboard, WinAPI, Mouse, Advanced Image Recognition, Windows handlers with MSAA or UI Automation implemented, etc.

5) Microsoft CUITS: Automation editor tool that implements tests CODED UI TESTS framework to control standard tests events such as test initialization, tests execution and tests finalization.

6) GreenSQA AiMaps ®: Graphical tool to easily create tests sequences, this contains components to execute AiMaps sequences usable directly from C Sharp, VS CUITS and GreenSQA INFramework. Typically AiMaps is used to perform actions over platforms where Visual Studio CUITS do not recognize user controls.

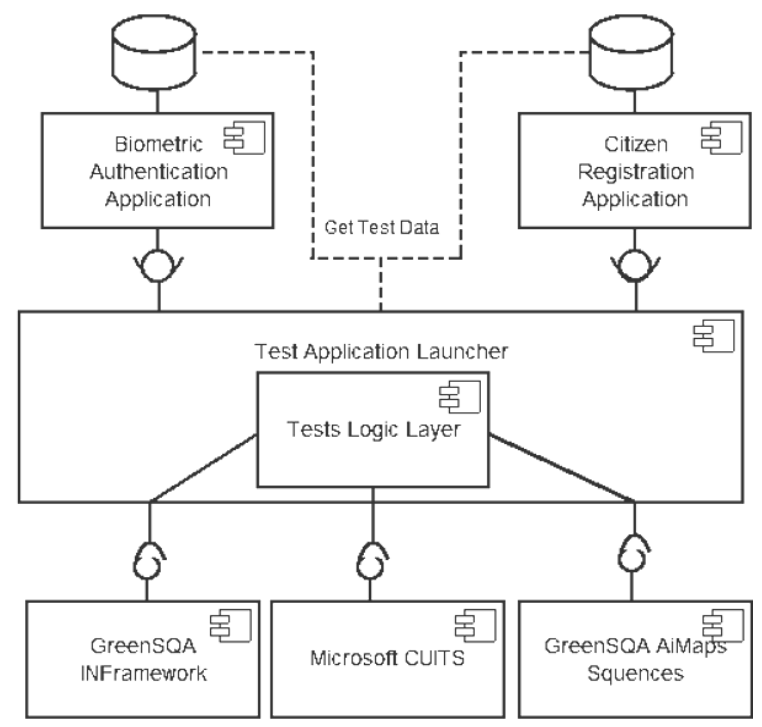

Fig. 3 Tests Automation - Components Diagram.
Observe that test data is taken directly from application under tests databases, so, is necessary to have keys to encrypt and decrypt data queries.

\section{Non Functional: Single Instance Strategy}

As shown in figure 4 , in a Colombian standard voting stand there could be 50 computers, if architecture for Biometric Application or Citizen Register Application don't support more than one instance on running machine you will need to define a test agent for each thread to simulate (a single thread will run sequentially all Application Automated Tests, see Tables II and II), and coordinate all test execution. GreenSQA have two approaches to achieve this goal:

1) VS Tests Settings File: Using tools like Visual Studio Load Tests, where tester defines a test setting file and configures all test agents in the same properties and drives test execution from only one single controller machine.

2) AiMaps Synchronization: Other Way is to use AiMaps and use their synchronization capabilities to perform same action at same time over multiple instances of running AiMaps Robots. Install performance monitor tools in server node to collect resource usage statistics during nonfunctional tests:

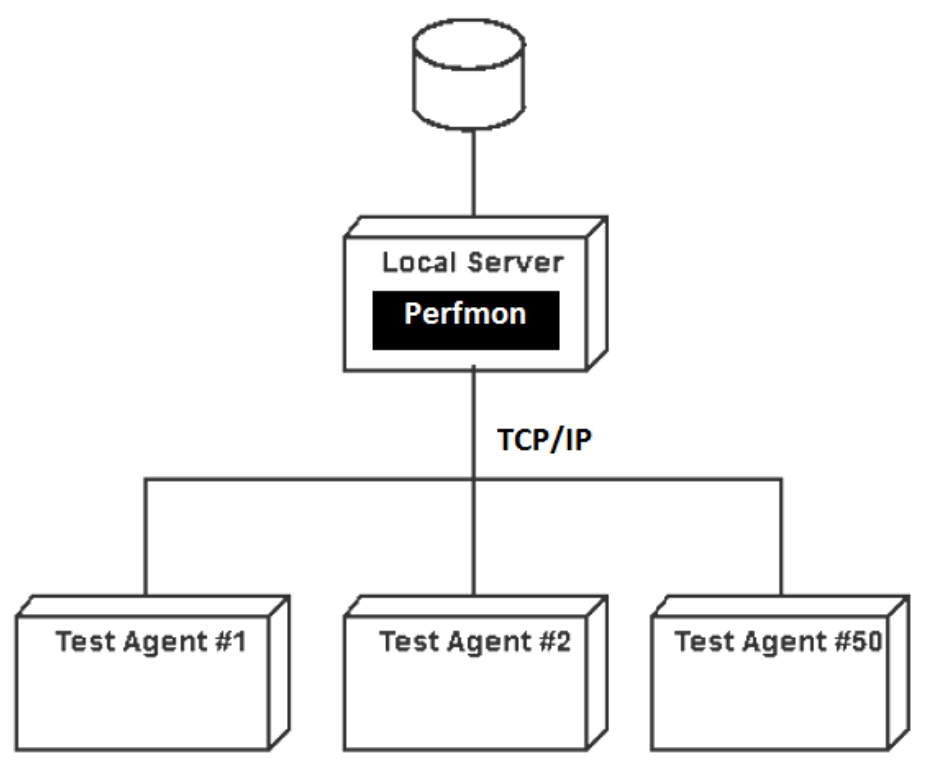

Fig. 4 Single Instance Strategy - Deployment Diagram

13 ${ }^{\text {th }}$ LACCEI Annual International Conference: "Engineering Education Facing the Grand Challenges, What Are We Doing?" July 29-31, 2015, Santo Domingo, Dominican Republic 


\section{E. Non Functional: Standard Strategy}

As shown in figure 5, if architecture for Biometric Application or Citizen Register Application support more than one instance on running machine you will need request to development team all interfaces to send information and execute system functions via web services or any other remote mechanism, after that need to define test agents to run recorded scripts. You need to create as many test agents as needed to achieve expected user loads:

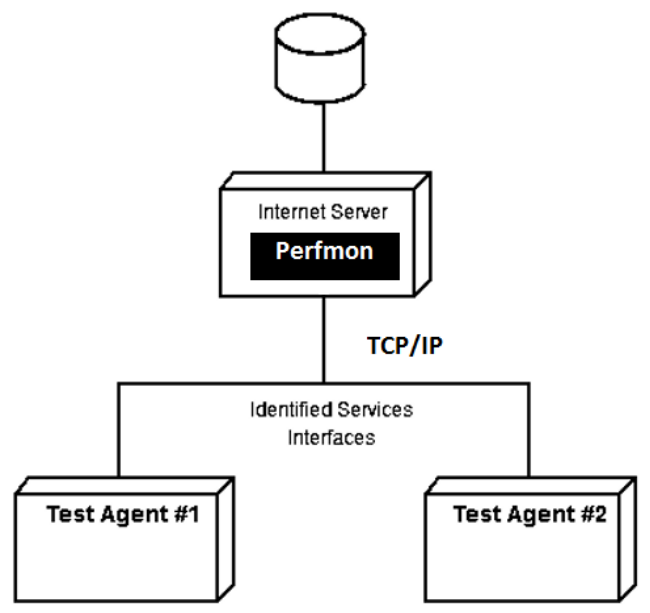

Fig. 5 Standard Strategy - Deployment Diagram

Install performance monitor tools in server node to collect resource usage statistics during nonfunctional tests.

\section{F. Non Functional Tests User Profiles}

In order to simulate real user interaction load with both of the applications Citizen Register and Biometric Authentication, GreenSQA execute three types of load profiles:

1) Lineal Profile: Used for load testing, virtual users remain connected repeating functional unit testing during the duration of the load. The test ends when the defined time expires or it could be when all test data were used.

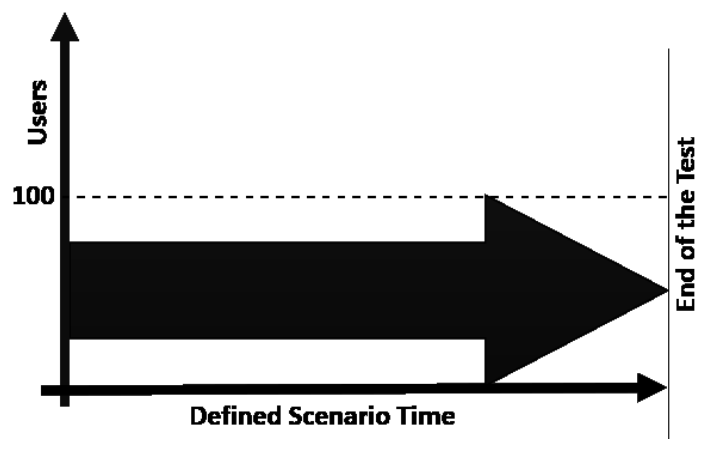

Fig. 6 Non Functional Lineal Profile
2) Simultaneous Profile: Used for concurrency tests, virtual users remain connected to execute the functional unit only once per virtual user. The test ends when each virtual user has executed its functional unit only at once.

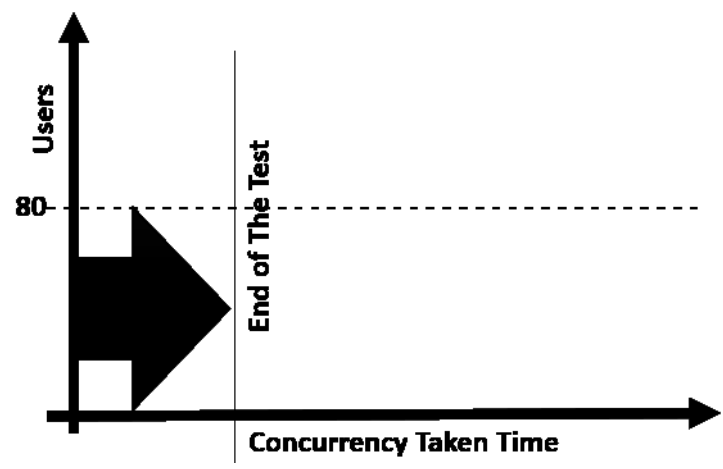

Fig. 7 Non Functional Concurrency Profile

2) Growing Profile: Used for stress testing when the slope is greater than or equal to $35^{\circ}$ is used to stress, otherwise is considered for load testing. In this profile, virtual users remain connected repeating functional tests.

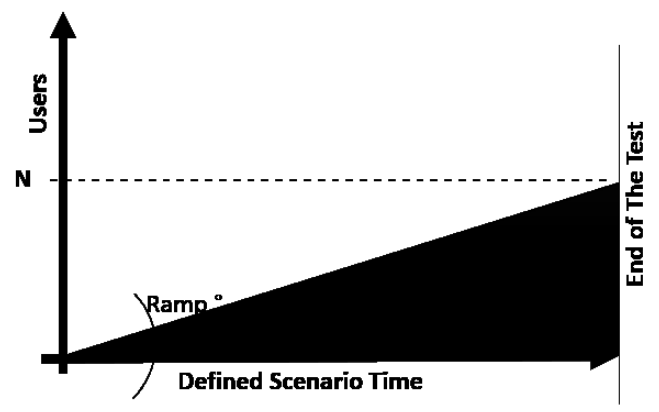

Fig. 8 Non Functional Growing Profile

The test ends when the set time expires or it could be when all test data were used.

\section{REFERENCES}

[1] Microsoft, (2015). MSDN documentation for Coded UI tests. MSDN Library, Visual Studio 2013, https://msdn.microsoft.com/enus/library/dd286726.aspx.

13 ${ }^{\text {th }}$ LACCEI Annual International Conference: "Engineering Education Facing the Grand Challenges, What Are We Doing?" 